\title{
Cell Cycle Progression in Gentamicin-Damaged Avian Cochleas
}

\author{
Sujata A. Bhave, Jennifer S. Stone, Edwin W Rubel, and Marc D. Coltrera \\ Virginia Merrill Bloedel Hearing Research Center and the Department of Otolaryngology-Head and Neck Surgery, \\ University of Washington, Seattle, Washington 98195
}

Hair cells, the sensory receptors of the auditory, vestibular, and lateral-line organs, may be damaged by a number of agents including aminoglycoside antibiotics and severe overstimulation. In the avian cochlea, lost hair cells can be replaced by regeneration These new hair cells appear to be derived from a support cell precursor which is stimulated to divide by events associated with hair cell loss. Little is known about the timing and sequencing of events leading to new hair cell production.

In this study cell cycle-associated events in the avian cochlea were analyzed at early and late time intervals following a single high dose of gentamicin. This single dose protocol has been shown to consistently result in extensive morphological damage and hair cell loss in the proximal region of the cochlea while sparing a morphologically undamaged distal cochlear region. This allowed for the differential analysis of the underlying support cell populations with respect to local hair cell loss. Three cell cycle associated markers were used to evaluate which cells entered and progressed through the cell cycle: statin, a $G_{0}$ associated nuclear marker; proliferating cell nuclear antigen (PCNA), a $G_{1}, S$ and $G_{2}$ associated marker; and 5-bromodeoxyuridine (BrdU), an $\mathrm{S}$ phase associated marker. Using these markers we found evidence for reversible changes in cell cycle status throughout the cochlea, while progression through $\mathbf{S}$ phase and mitosis was restricted to the region of the cochlea which sustained hair cell loss.

[Key words: gentamicin, cochlea, hair cell regeneration, cell cycle, proliferating cell nuclear antigen (PCNA), 5-bromodeoxyuridine (BrdU), statin]

Hair cells, the sensory receptors of the auditory, vestibular, and lateral-line organs, may be damaged by a number of agents including aminoglycoside antibiotics and severe overstimulation. Previous studies have demonstrated that new hair cell production occurs throughout life in the auditory and vestibular epithelium in fish and amphibians, and in avian vestibular end organs (Corwin, 1985; Jorgensen and Mathiesen, 1988; Popper and Hoxter, 1990; Presson and Popper, 1990; Roberson et al., 1992). Analogous ongoing production of auditory hair cells during postcmbryonic life does not appear to occur in avian and mammalian

\footnotetext{
Received Oct. 1, 1991; revised Dec. 30, 1994; accepted Jan. 11, 1994.

We thank Dale Cunningham for valuable technical assistance and Eugenia Wang, Ph.D., for the gift of the statin antibody. This work was supported by Grants CA-36250, DC-00035, and DC-00395 from the National Institutes of Health, funds from the National Organization for Hearing Research and funds from the Oberkotter Foundation.

Correspondence should be addressed to Marc D. Coltrera, M.D., Department of OTO-HNS RL-30, University of Washington, Seattle, WA 98195.

Copyright (C 1995 Society for Neuroscience $0270-6474 / 95 / 154618-11 \$ 05.00 / 0$
}

sensory epithelium. However, after trauma-induced hair-cell death, lost hair cells can be replaced in the avian auditory sensory epithelium by regeneration (Cotanche, 1987; Cruz et al., 1987; Corwin and Cotanche, 1988; Ryals and Rubel, 1988).

Several recent investigations have focused on identifying the precursor cells for new hair cells in the avian inner ear. Potential hair cell precursors include supporting cells, embryonic-like neuroepithelial cells and cells located immediately adjacent to the sensory epithelium (Girod et al., 1989; Raphael, 1992; Weisleder and Rubel, 1993; Stone and Cotanche, 1994; Tsue et al., 1994b). The preponderance of the evidence suggests that new hair cells are primarily derived from a support cell precursor which is stimulated to divide by events associated with the loss of hair cells. Little is known about the cellular events that trigger this proliferation and previous studies have not addressed the timing and sequencing of events in the sensory epithelial cell populations as the cells are stimulated to enter and progress through the cell cycle.

In this study we looked at cell cycle associated events in the avian cochlea at early and late time intervals following gentamicin induced damage of the auditory epithelium. A single high dose of gentamicin, previously shown to cause a consistent amount and pattern of hair cell loss was used to initiate the regenerative events (Janas et al., 1994). The resulting damage pattern consisted of extensive morphological damage and hair cell loss in the proximal region of the cochlea and a morphologically undamaged distal cochlear region, allowing for differential analysis of the underlying support cell populations. Three cell cycle associated markers were used to evaluate which cells entered and progressed through the cell cycle: statin, a $G_{0}$ associated nuclear marker; proliferating cell nuclear antigen (PCNA), a $\mathrm{G}_{1}, \mathrm{~S}$ and $\mathrm{G}_{2}$ associated marker; and 5-bromodeoxyuridine (BrdU), an S phase associated marker (Gratzner, 1982; Wang, 1985a; Bravo et al., 1987). Using these markers we found evidence for reversible changes in cell cycle status throughout the cochlea, while progression through $S$ phase and mitosis was restricted to the region of the cochlea which sustained hair cell loss.

A preliminary report of these data has been presented (Bhave et al., 1994).

\section{Materials and Methods \\ Subjects}

Fertilized eggs of the White Leghorn variety (Gallus domesticus) were obtained from a local supplier (H\&N International, Redmond, WA) and incubated at $37^{\circ} \mathrm{C}$. Posthatch chicks were maintained in the animal care facility prior to experimental use. Chicks were sacrificed by sodium pentobarbital overdose administered intraperitoneally. All experimental protocols were reviewed and approved by the University of Washington Animal Care Committee. 
Table 1a. Mean statin level percentages (with SD) in hair cells across the length of the basilar papilla in control and experimental chicks days 1, 3, 5, and 20

\begin{tabular}{rccccc} 
& Distance & & & \\
\cline { 2 - 3 } \cline { 5 - 6 } & $600 \mu \mathrm{m}$ & $1200 \mu \mathrm{m}$ & & $1800 \mu \mathrm{m}$ & $2400 \mu \mathrm{m}$ \\
\hline Control $(n=7)$ & $91(3.9)$ & $67(9.9)$ & & $60(15.7)$ & $70(19.5)$ \\
1 d post-gentamicin $(n=3)$ & $49(42.4)^{* *}$ & $86(8.1)$ & & $88(7.6)$ & $81(9.0)$ \\
3 d post-gentamicin $(n=3)$ & $6(6.0)^{* *}$ & $4(7.5)^{* *}$ & & $5(5.2)^{* *}$ & $4(0.57)^{* *}$ \\
5 d post-gentamicin $(n=3)$ & $0(0.00)^{*}$ & $34(5.5)^{* *}$ & & $38(9.2)^{* *}$ & $28(10.4)^{* *}$ \\
20 d post-gentamicin $(n=3)$ & $65(14.0)^{*}$ & $92(14.9)$ & & $73(7.0)$ & $66(9.6)$ \\
\hline
\end{tabular}

All $p$ values were derived from single factorial ANOVA comparison with control groups.

"No hair cells present in this region.

* Significantly lower than control value, $p<0.05$.

$* *$ Significantly lower than control value, $p<0.01$.

\section{Gentamicin injection}

Three-day-old chicks were given a single subcutaneous dose of gentamicin sulfate $(250 \mathrm{mg} / \mathrm{kg}$; Lyphomed, Deerfield, IL). Age-matched control chicks received no drug injections. The chicks were divided into groups based on the length of survival following gentamicin injection: $1,3,5,7$, and 20 d groups. The number of animals in each experimental group is listed in Tables $1-3$.

\section{Bromodeoxyuridine injections}

Chicks in the short term post-BrdU survival groups received injections of the thymidine analog BrdU following different periods of recovery after gentamicin injection to assess the number, timing and position of cells entering $S$ phase. A single series of three intraperitoneal injections of BrdU (100 mg/kg; Sigma, St. Louis, MO) were given $4 \mathrm{hr}$ apart on day $1,3,5$, or 7 after gentamicin injection. BrdU injections were initiated at the same time of day for each animal. Age-matched control animals corresponding to the 3 and $5 \mathrm{~d}$ post-gentamicin injection groups also received BrdU, but no gentamicin. Chicks were sacrificed $24 \mathrm{hr}$ after the first BrdU injection.

To determine the fate of cells that incorporate BrdU following injections at $5 \mathrm{~d}$ after gentamicin treatment, a long term post-BrdU group of chicks was given the same series of BrdU injections as described above on day 5 and then allowed to recover for $15 \mathrm{~d}$. Age-matched control animals received $\mathrm{BrdU}$ injections, but no gentamicin.

\section{Tissue preparation}

Scanning electron microscopy. Scanning electron microscopy was performed on cochleas from two birds from each post-gentamicin treatment group $(1,3,5$, and $20 \mathrm{~d})$ and from each of the age-matched control groups. Following euthanasia, microdissection of the ears was performed and the cochlear ducts were perfused with a fixative consisting of $2.5 \%$ glutaraldehyde, $1 \%$ paraformaldehyde, $0.1 \mathrm{M}$ sucrose, $5 \mathrm{~mm}$ $\mathrm{MgSO}_{4}$ in phosphate-buffered saline (PBS, pH 7.4). The temporal bones were immersion fixed overnight. Tissue was postfixed in $1 \%$ osmium tetroxide in PBS for $1 \mathrm{hr}$. After PBS washes, the tectorial membrane was dissected and the tissue was subjected to serial dehydration steps followed by critical point drying. Specimens were mounted on aluminum studs, coated with pure gold, and examined with a JEOL microscope (model JEM 6300F).

PCNA, statin, and BrdU. For PCNA and statin analysis, the cochlear ducts were perfused with methanol-Carnoys fixative for $5 \mathrm{~min}$. The temporal bones were then immersion fixed in the same fixative overnight at $4{ }^{\circ} \mathrm{C}$. Following alcohol rinses, the cochlear ducts were removed from the temporal bones, dehydrated in graded alcohols, cleared in methyl salicylate and paraffin embedded. Beginning at the proximal end, the entire cochlea was serially sectioned into $5 \mu \mathrm{m}$ thick tissue sections. Sets of seven sequentially cut tissue sections were collected at $600 \mu \mathrm{m}$ intervals measured from the proximal end of the cochlea and the sections were mounted on chrome-alum-subbed slides. The first six slides from each set were immunostained for PCNA or statin in alternating order, while the seventh slide was stained with thionin in order to count the number of cells in each region.

For BrdU analysis the temporal bones were dissected in cold Hanks' buffered saline solution (HBSS). Most of the bone and cartilage surrounding each cochlear duct and the tegmentum vasculosum were removed. Cochlear ducts (still partially supported by the remaining bone) were placed in collagenase Type I $(0.0007 \mathrm{gm} / 10 \mathrm{ml} \mathrm{HBSS}$; Sigma) for $3 \mathrm{~min}$, and tectorial membranes were removed. Cochleas were then rapidly rinsed in fresh HBSS and fixed in $4 \%$ paraformaldehyde $(\mathrm{pH}$ 7.4) for $20 \mathrm{~min}$. Following PBS washes, cochleas were stored in PBS at $4^{\circ} \mathrm{C}$ prior to $\mathrm{BrdU}$ immunohistochemistry.

\section{Immunohistochemistry}

All the incubations were carried out at room temperature with PBS washes between steps unless otherwise stated.

PCNA and statin immunohistochemistry. After deparaffinization and rehydration, endogenous peroxidase activity was blocked using $0.3 \%$ $\mathrm{H}_{2} \mathrm{O}_{2}$ for 10 min, followed by $0.1 \%$ Triton $\times 100,0.5 \%$ BSA in PBS for $7 \mathrm{~min}$ and $4 \%$ normal horse serum for $45 \mathrm{~min}$. Anti-PCNA monoclonal antibody 19A2 (1:4000 in 1\% BSA/PBS; Coulter Immunology, Hialeah, FL) or anti-statin monoclonal antibody $\mathrm{S} 44(1: 25,000$ in $1 \%$ BSA/PBS; gift of E. Wang, Toronto, Canada) was incubated on the tissue sections in a moist chamber overnight at $4^{\circ} \mathrm{C}$. In the case of $19 \mathrm{~A} 2$

Table 1b. Mean statin level percentages (with SD) in support cells across the length of the basilar papilla in control and experimental chicks days $1,3,5$, and 20

\begin{tabular}{rllll} 
& Distance & & \\
\cline { 2 - 5 } & $600 \mu \mathrm{m}$ & $1200 \mu \mathrm{m}$ & $1800 \mu \mathrm{m}$ & $2100 \mu \mathrm{m}$ \\
\hline Control $(n=7)$ & $62(16.8)$ & $68(15.6)$ & $65(14.8)$ & $65(11.0)$ \\
1 d post-gentamicin $(n=3)$ & $50(43.7)$ & $81(6.5)$ & $83(1.5)$ & $67(24.3)$ \\
3 d post-gentamicin $(n=3)$ & $12(5.5)^{*}$ & $18(8.5)^{* *}$ & $21(6.4)^{* *}$ & $35(25.6)$ \\
5 d post-gentamicin $(n=3)$ & $6(3.7)^{* *}$ & $34(21.7)^{* *}$ & $41(4.0)^{* *}$ & $30(1.5)^{*}$ \\
20 d post-gentamicin $(n=3)$ & $99(1.15)$ & $68(11.1)$ & $59(3.0)$ & $61(7.5)$
\end{tabular}

All $p$ values were derived from single factorial ANOVA comparison with control groups.

* Significantly lower than control value, $p<0.05$.

$* *$ Significantly lower than control value, $p<0.01$. 
Table 2. Mean PCNA level percentages (with SD) in support cells across the length of the basilar papilla in control and experimental chicks days $1,3,5,7$, and 20

\begin{tabular}{rlllc} 
& Distance & & \\
\cline { 2 - 5 } & $600 \mu \mathrm{m}$ & $1200 \mu \mathrm{m}$ & $1800 \mu \mathrm{m}$ & $2400 \mu \mathrm{m}$ \\
\hline Control $(n=7)$ & $3(3.0)$ & $2(4.4)$ & $3(5.1)$ & $5(5.3)$ \\
1 d post-gentamicin $(n=3)$ & $20(7.0)$ & $16(2.0)$ & $11(3.0)$ & $9(5.0)$ \\
3 d post-gentamicin $(n=3)$ & $25(33.3)^{*}$ & $35(27.0)^{* * *}$ & $17(8.5)$ & $7(2.6)$ \\
5 d post-gentamicin $(n=3)$ & $33(3.6)^{* *}$ & $65(7.5)^{* *}$ & $40(1.5)^{* *}$ & $25(2.0)^{* *}$ \\
7 d post-gentamicin $(n=3)$ & $26(4.6)^{*}$ & $27(11.0)^{* *}$ & $28(7.7)^{*}$ & $13(2.6)^{*}$ \\
20 d post-gentamicin $(n=3)$ & $26(14.1)^{*}$ & $29(4.5)^{* *}$ & $40(43.2)^{* *}$ & $14(6.2)^{*}$
\end{tabular}

All $p$ values were derived from single factorial ANOVA comparison with control groups.

* Significantly greater than control value, $p<0.05$.

** Significantly greater than control value, $p<0.01$.

secondary biotinylated anti-mouse IgG $(\mathrm{H}+\mathrm{L})(1: 400 \mathrm{in} 1 \% \mathrm{BSA} / \mathrm{PBS}$; Vector Labs, Burlingame, CA) was applied for $45 \mathrm{~min}$ at $37^{\circ} \mathrm{C}$ while secondary biotinylated anti-mouse $\operatorname{IgM}(1: 400$ in $1 \% \mathrm{BSA} / \mathrm{PBS}$; Vector Labs) was applied for $30 \mathrm{~min}$ at $4^{\circ} \mathrm{C}$ for $\mathrm{S} 44$. Peroxidase-conjugated streptavidin (1:5000 in 1\% BSA/PBS; Vector Labs) was incubated for $30 \mathrm{~min}$, and the reaction was developed in $3,3^{\prime}$ diaminobenzidine (DAB; $0.25 \mathrm{mg} / \mathrm{ml}$; Sigma) in $0.05 \mathrm{M}$ Tris HCL (pH 7.6) at room temperature with $\mathrm{NiCl}_{2}$ enhancement (Hsu and Soban, 1982). The sections were then dehydrated and coverslipped.

Positive immunohistochemical control tissues consisted of chicken gut for PCNA and chicken leg skin for statin, processed with the same embedding and immunohistochemistry protocols. Negative immunohistochemistry controls were incubated with normal mouse serum (1: 10,000 in $1 \% \mathrm{BSA}$ ) overnight at $4^{\circ} \mathrm{C}$ in place of the primary antibodies.

BrdU immunohistochemistry. To detect BrdU-labeled cells, the protocol originally established by Raphael (1992) and modified by Stone and Cotanche (1994) for BrdU immunohistochemistry in cochlear whole-mounts was followed. Cochlear ducts were placed in $2 \mathrm{~N} \mathrm{HCl}$ diluted in $0.05 \%$ Triton X-100 in PBS for 20 min at $37^{\circ} \mathrm{C}$. Cochleas were then dissected from the remaining temporal bone. The tissue was placed in $0.05 \%$ hydrogen peroxide in PBS $(\mathrm{pH} \mathrm{7.8)}$ for $15 \mathrm{~min}$ and then $5 \%$ normal goat serum in $0.05 \%$ Triton $\times 100$ in PBS. Wholemounts were incubated with mouse anti-BrdU monoclonal antibody (1: 40 in $0.05 \%$ Triton X-100/PBS; Becton Dickenson, San Jose, CA) for $1 \mathrm{hr}$, biotinylated horse anti-mouse IgG $(1: 200$ in $0.05 \%$ Triton X-100/ PBS; Vector Labs) for $30 \mathrm{~min}$, and avidin-biotin with horseradish peroxidase (1:50 in $0.05 \%$ Triton X-100/PBS; Vector Labs) for $45 \mathrm{~min}$. Whole-mounts were then placed in $0.05 \mathrm{M}$ TRIS buffer $(\mathrm{pH} 7.4$ ) followed by DAB $(0.25 \mathrm{mg} / \mathrm{ml}$; Sigma) in $0.05 \mathrm{M}$ TRIS for $5 \mathrm{~min}$ and DAB $/ 0.005 \% \mathrm{H}_{2} \mathrm{O}_{2}$ for 3 min. Tissue was mounted onto slides in $90 \%$ glycerol in PBS and coverslipped. For negative controls, cochleas from

Table 3. Mean BrdU levels (with SD) across the length of the basilar papilla in control and experimental chicks days 1, 3, 5, 7, and 20

\begin{tabular}{lcl} 
& Distance & \\
\cline { 2 - 3 } & Proximal & Distal \\
\hline Control $(n=8)$ & $0(0.0)$ & $1(1.6)$ \\
1 d post-gentamicin $(n=7)$ & $5(3.8)$ & $0(0.37)$ \\
3 d post-gentamicin $(n=4)$ & $218(133.7)^{* *}$ & $1(2.5)$ \\
5 d post-gentamicin $(n=8)$ & $27(12.5)^{++}$ & $3(2.5)$ \\
7 d post-gentamicin $(n=8)$ & $3(1.6)$ & $2(1.7)$ \\
20 d post-gentamicin & $22(13.6)^{++}$ & $1(0.9)$ \\
(long-term post-BrdU) $(n=7)$ & &
\end{tabular}

All $p$ values derived from single factorial ANOVA comparison with control groups.

** Significantly higher than all other groups, $p<0.01$.

${ }^{++}$Significantly higher than control group when variance is adjusted for lack of homogeneity. gentanicin and BrdU injecled chicks ( 5 d group, $n=2$ ) were processed in the same manner, but with omission of the primary antibody.

\section{Tissue analysis}

PCNA and statin immunohistochemistry analysis. Sections were analyzed by quantitative microscopy using NIH IMAGE $1.52 \mathrm{~b} 77$ (Research Services Branch, NIMH, Bethesda, MD) on a Macintosh IIcx computer. Slides were digitized by a video camera attached to a Zeiss Universal microscope with a $100 \times$ objective. Only nuclei lying in a single focal plane were counted. Since the presence of intact stereocilia can be difficult to determine in the immunohistochemical preparation, hair cells were identified by the following criteria: location of the cell body at the lumenal surface of the sensory epithelium and presence of dark cytoplasm and a cuticular plate. Support cells were identified by lighter stained cytoplasm and basal location of nuclei. To aid in identification of hair cell and support cell nuclei and for quantitative microscopy purposes, each cross section was divided into three equidistant segments (superior, middle, inferior) measured across the width of the basilar membrane. The number of immunohistochemically positive nuclei in each segment was then converted into a density measure of nuclei per $100 \mu \mathrm{m}$ of basilar membrane width. The three density measurements taken from each cross section were then combined and averaged to derive a single nuclear density measurement for each cell type in each cochlear cross section. Separate total nuclear density measurements were derived for hair cell and support cell nuclei using the corresponding thionin-stained slide. Finally, the percentage of PCNA and statin labeled nuclei for the hair cell layer and support cell layer was then calculated by dividing the immunostained nuclear density by the total nuclear density. To verify the reproducibility of the analysis, $20 \mathrm{ran}$ domly selected sections from two animals underwent an additional blinded analysis by two independent ohservers and were also analyzed twice by the same observer. No significant inter/intraobserver differences in resulting cell counts were found $(0.93$, Spearman rank correlation).

BrdU immunohistochemistry analysis. Whole-mounts were examined on a Leica Axioplan microscope using Nomarski optics and a $100 x$ objective. The epithelium was compartmentalized along its length into $600 \mu \mathrm{m}$ regions by measuring along the mid-width line of the epithelium starting at the proximal end and extending to the apical end. BrdUlabeled nuclei were counted within each $600 \mu \mathrm{m}$ compartment. Counts from the first two $600 \mu \mathrm{m}$ compartments $(0-1200 \mu \mathrm{m})$, corresponding to the morphologically damaged region, were combined to attain a value for the proximal region. Since the region between 1200 and $1800 \mu \mathrm{m}$ typically represents the zone of transition between the morphologically damaged and undamaged portions of the epithelium, labeled cells within this region were not counted in order to minimize errors in assigning labeled cells to either the damaged or undamaged region. Counts from $1800 \mu \mathrm{m}$ to the distal end were combined to attain a value for the distal region. In order to only count labeled cells within the sensory epithelium, great care was taken to strictly avoid focal planes at or below the level of the basilar membrane so as to exclude labeled tympanic border cells and stromal cells (Girod et al., 1989).

One-way and two-way analyses of variance (ANOVA) were performed for each immunohistochemical marker with respect to post-gentamicin survival group and cochlear region. Statistical analysis was per- 

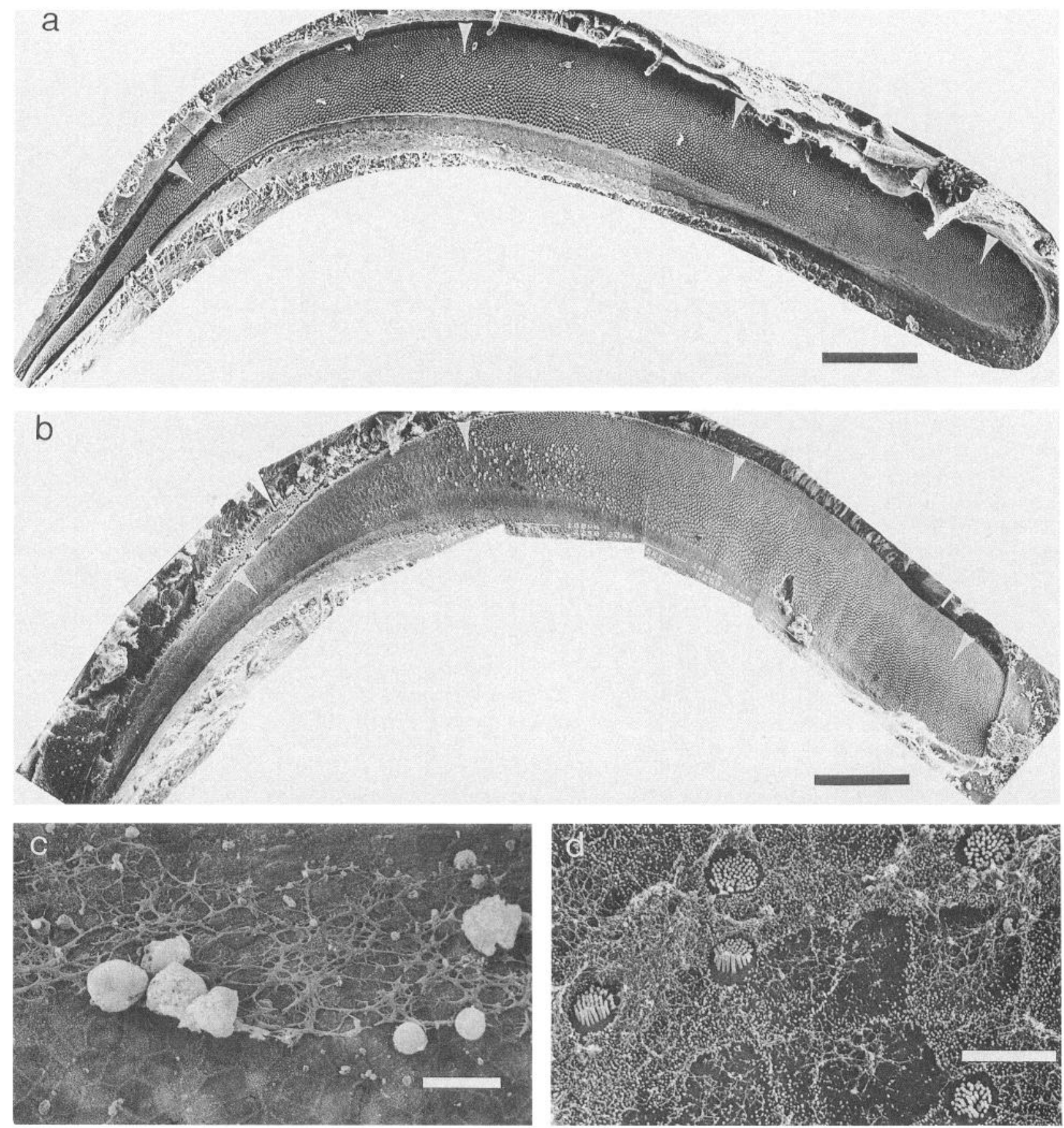

Figure 1. Scanning electron photomicrographs of chick cochlea. $a$, Normal control cochlea with intact hair cells. $b$, Three days post-gentamicin, widespread loss of hair cells is evident at the proximal end (left). $c$, Higher power view of morphologically damaged proximal end at $3 \mathrm{~d}$ demonstrating complete loss of hair cells. $d$, Higher power view of morphologically damaged proximal end at $5 \mathrm{~d}$ post-gentamicin demonstrating the appearance of new hair cells. Scale bars: $a$ and $b, 200 \mu \mathrm{m} ; c, 10 \mu \mathrm{m} ; d, 5 \mu \mathrm{m}$.

formed on a Macintosh computer using STATVIEW 4.1 software package (Abacus Concepts, Berkeley, CA).

\section{Results}

The results are presented for the control groups and then for each of the experimental groups in sequential order of survival times. Quantitative data comparing the percentages of. PCNA and statin immunopositive cells and the number of BrdU immunopositive cells in each group are presented in Tables 1-3. The number of animals and significance values for quantitative analyses are indicated in the tables.

\section{Control group}

Scanning electron microscopy. The chick cochlea contains an elongated sickle shaped sensory epithelium (Fig. 1a). As described by Takasaka and Smith (1971), the proximal portion of the epithelium is narrow compared with the distal portion. The sensory epithelium is located between the superior fibrocartilaginous plate (convex side), where the nerve fibers enter and the inferior fibrocartilaginous plate (concave side). As viewed from above, hair cell surfaces form a hexagonal array at the lumenal surface of the epithelium. They are characterized by the presence 
Figure 2. Histologic cross section of an undamaged cochlea divided into superior $(I)$, middle $(I I)$, and inferior segments (III) (see text). Scale bar, $70 \mu \mathrm{m}$.

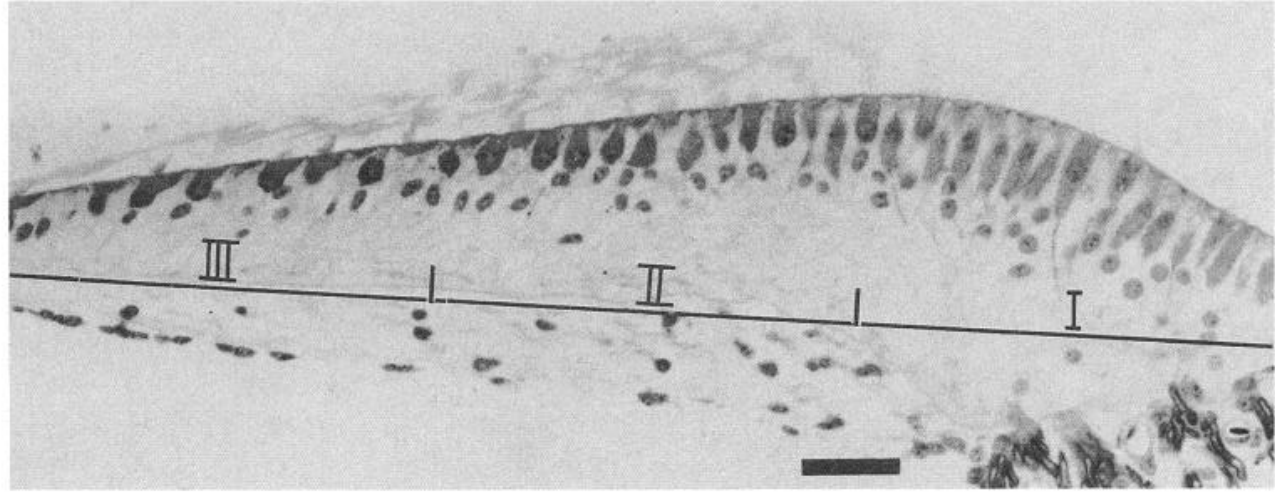

of stereocilia with surrounding support cells containing numerous microvilli.

Light microscopy. As previously stated, the cross-sectional area of the normal sensory epithelium can be divided into three roughly equal segments; superior, middle, and inferior (Fig. 2). The superior segment is the region resting on the superior fibrocartilaginous plate where the nerve enters while the inferior segment is bounded by the hyaline cells. Detailed description of the sensory epithelium of the avian basilar papilla (cochlea) can be found in the classic paper by Takasaka and Smith (1971) and has been reviewed more recently by Manley (1990). The normal sensory epithelium consists of hair cells which are located at the lumenal surface and supporting cells which extend from the basilar membrane to the lumenal surface. The hair cells are characterized by the presence of stereocilia, a cuticular plate, dark staining cytoplasm, nuclei located just below the lumenal surface and cell membranes which do not contact the basilar membrane. Support cells are identifiable by their lighter staining cytoplasm and nuclei which are located nearer the basilar membrane (Girod et al., 1989). During development the anlage of the sensory epithelium is a true pseudostratified epithelium. As found in developing neural epithelium, the nuclei of the proliferating cells translocate from the basement membrane to the luminal surface during the transition from S-phase to M-phase of the cell cycle (Katayama and Corwin, 1993). Similarly, during hair cell regeneration M-phase nuclei are found near the luminal surface while S-phase nuclei are closer to the basement membrane in both the cochlea and the vestibular epithelium of birds (Raphael, 1992; Stone and Cotanche, 1994; Tsue et al., 1994b). It is not known presently if the proliferating cell maintains contact with the basement membrane throughout the cell cycle and, if so, when differentiating regenerated hair cells loose this basal extension.

Statin label. Statin immunoreactivity is seen in the nucleus with the greatest concentration of staining around the periphery. In the chicken skin control statin expression was largely absent in the basal proliferating layer with increasing expression in the upper terminally differentiated epithelial layers. Chick striated muscle nuclei underlying the skin were also positive for statin. In the undamaged cochlea, statin expression by cells in the sensory epithelium was identifiable in an average of $71 \%$ of hair cells and $62 \%$ of support cells for the whole cochlea (Fig. $3 a, b$; Table 1). Other statin positive cell populations included the hyaline cells, cells of the tegmentum vasculosum, homogene cells, cuboidal cells, cells lining the basilar membrane and chondrocytes in the fibrocartilaginous plate. It is important to note that the absence of statin staining, as with any immunohistochemical technique, does not necessarily indicate absence of the molecule; expression could be below the level detectable by immunohistochemistry or antibody penetration into the tissue section could be incomplete.

PCNA label. PCNA immunostaining is detected as a granular pattern in the nucleus along with a more diffuse nucleoplasmic reaction product. In control tissue, PCNA staining was located at the base of the intestinal crypts and in the basal layer of the chick skin. In the control, undamaged cochlea, PCNA stained cells were rare. An average of $3 \%$ of the support cell population labeled for PCNA with a slight increase in PCNA labeling in the distal $(2400 \mu \mathrm{m})$ region compared with the more proximal region (Fig. 4a,b; Table 2). No hair cells in any undamaged control cochleas were labeled for PCNA. Among other cochlear cell populations, scattered cells were PCNA labeled among the tegmentum vasculosum cells, tympanic border cells, hyaline cells, homogene cells, and the chondrocytes of the fibrocartilaginous plate.

BrdU label. Immunohistochemical staining of BrdU was identifiable as a stippled nuclear pattern. In the proximal end of the epithelium $(0-1200 \mu \mathrm{m})$, no BrdU-labeled nuclei were detected in control animals (Fig. $5 a, b$; Table 3 ). In the distal end of the epithelium (1800 $\mu \mathrm{m}$ to the most distal pole) an average of one labeled nucleus per region was detected. Except for a single pair of labeled nuclei, the BrdU-labeled nuclei were present as single cells. Focusing through the whole-mount tissue demonstrated that the majority of labeled cells were present at mid-depth in the region containing support cell nuclei.

\section{One day post-gentamicin}

Scanning electron microscopy. On postinjection day 1, the proximal $0-400 \mu \mathrm{m}$ of the sensory epithelium contained areas with swollen hair cells and rare hair cell loss while the rest of the epithelium appeared normal (see Fig. $1 b$ for damage at 3 d).

Light microscopy. Cross sections at $600 \mu \mathrm{m}$ from the proximal end did not demonstrate any detectable loss of hair cells. This was consistent with the scanning microscopy findings which demonstrated that hair cell loss was confined to the proximal $400 \mu \mathrm{m}$ region. Sections from the more distal intervals $(1200 \mu \mathrm{m}, 1800 \mu \mathrm{m}$, and $2400 \mu \mathrm{m})$ also appeared normal.

Statin label. Statin label at the proximal $600 \mu \mathrm{m}$ interval was detected in only $49 \%$ of hair cells as compared to $91 \%$ in the control group (Fig. $3 c, d$; Table 1). Hair cell labeling in the rest of the epithelium demonstrated a small increase in statin label. Fifty percent of the support cells at the $600 \mu \mathrm{m}$ interval labeled with statin, whereas $62 \%$ of support cells labeled in the controls. Statin labeling in the support cells from the more distal intervals was not significantly changed from controls. 

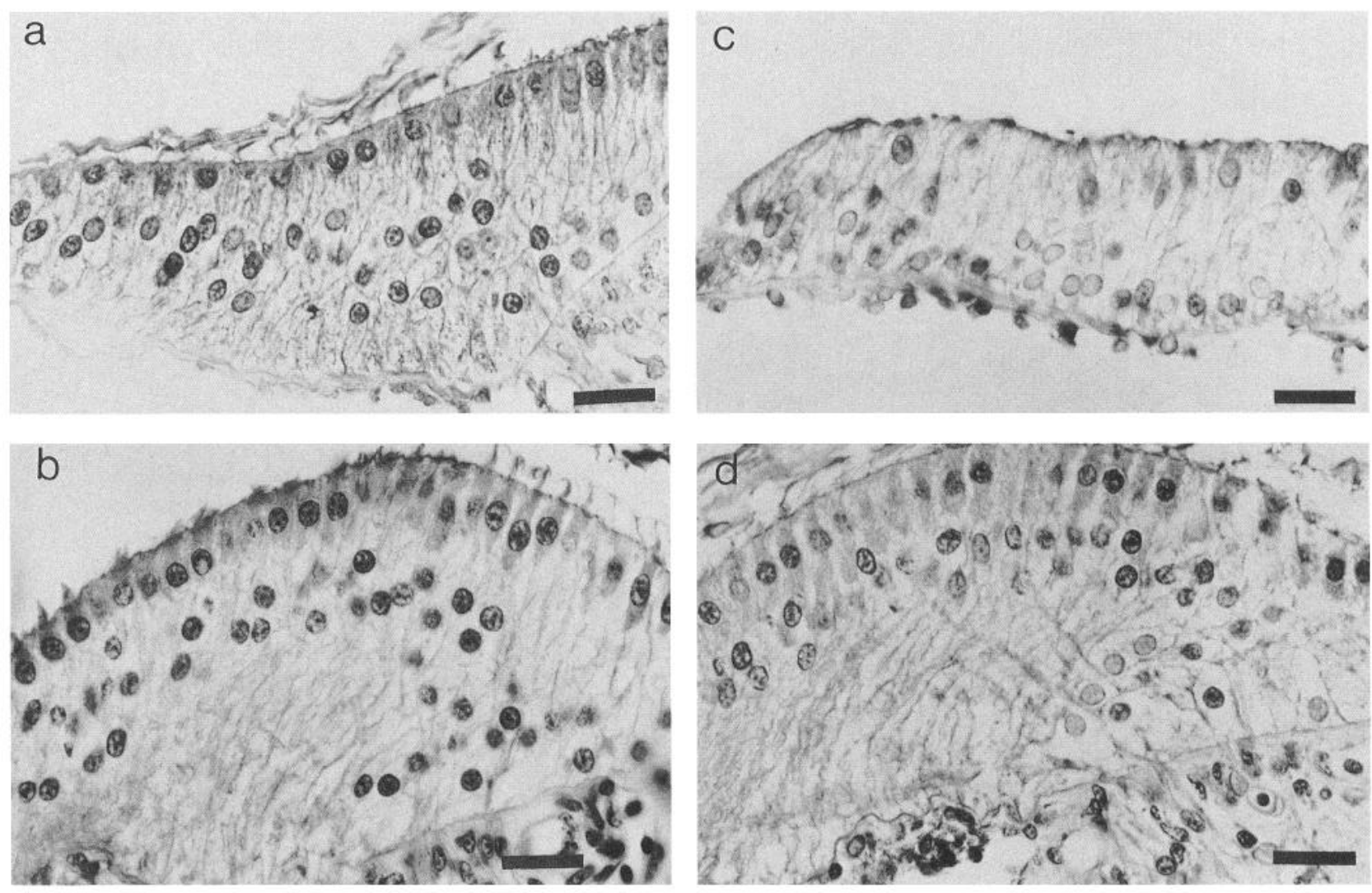

Figure 3. Photomicrographs of statin immunohistochemical staining. $a$ and $b$, Normal control cochlea demonstrating a high percentage of statin positive cells in the proximal $(a)$ and distal $(b)$ regions. $c$ and $d$, Five days post-gentamicin: statin expression decreases in both the proximal (c) and distal $(d)$ regions. Scale bars, $30 \mu \mathrm{m}$.

PCNA label. No hair cells were found to be PCNA labeled. Support cells in the proximal intervals, $600 \mu \mathrm{m}$ and $1200 \mu \mathrm{m}$, demonstrated an increase in PCNA label $(20 \%$ and $16 \%$, respectively) compared with normal controls, while a lesser increase was found in the distal intervals $1800 \mu \mathrm{m}$ and $2400 \mu \mathrm{m}$ (11\% and $9 \%$, respectively) (Fig. $4 c, d$; Table 2). While these values were consistently above control levels, none reached statistical significance.

$B r d U$ label. On average, five BrdU-labeled nuclei were detected in the proximal, morphologically damaged region while no labeled nuclei were found in the distal, morphologically undamaged region of most animals in this group (Table 3 ).

\section{Three days post-gentamicin}

Scanning electron microscopy. By day 3 there was extensive morphological damage in the hair cell layer from the proximal tip to $1000-1200 \mu \mathrm{m}$ from the proximal end; all hair cells in this region had been lost (Fig. 1b,c). Compared with the extensive morphological damage noted in the proximal end, a "marginal" zone in the mid-cochlea $(1200-1800 \mu \mathrm{m})$ demonstrated variable degrees of damage. Edematous hair cells with widening and blebbing of the stereocilia and support cells with increased surface areas were evident. The epithelium beyond the marginal zone $(>1800 \mu \mathrm{m})$ remained morphologically normal in appearance.

Light microscopy. By $3 \mathrm{~d}$ post-gentamicin most of the hair cells were lost and the cytoarchitecture was severely disrupted in the proximal $600 \mu \mathrm{m}$ interval. The epithelium was thinner than normal controls and there was considerable variation in support cell nuclear sizes. At $1200 \mu \mathrm{m}$, all short hair cells were lost, but a few tall hair cells were still present (Takasaka and Smith, 1971). No visible hair cell loss, or disturbance of the normal cellular architecture was found at $1800 \mu \mathrm{m}$ and 2400 $\mu \mathrm{m}$.

Statin label. Statin labeling in the hair cells (Table 1a) was further reduced compared with the $1 \mathrm{~d}$ post-gentamicin group both for the remaining hair cells in the morphologically damaged $600 \mu \mathrm{m}$ and $1200 \mu \mathrm{m}$ intervals (6\% and $4 \%$, respectively) and for the hair cells in the morphologically undamaged distal region $(5 \%)$. Statin labeling in support cells (Table 1b) was similarly reduced in all regions $(600 \mu \mathrm{m}, 12 \% ; 1200 \mu \mathrm{m}, 18 \% ; 1800 \mu \mathrm{m}$, $21 \% ; 2400 \mu \mathrm{m}, 35 \%)$.

PCNA label. No hair cells were found to be PCNA labeled. The number of PCNA labeled support cells was markedly increased compared to the $1 \mathrm{~d}$ post-gentamicin group in the proximal, morphologically damaged regions $600 \mu \mathrm{m}$ and $1200 \mu \mathrm{m}$ (25\% and $35 \%$, respectively) while the distal, morphologically undamaged regions $1800 \mu \mathrm{m}$ and $2400 \mu \mathrm{m}$ demonstrated a more moderate increase $(17 \%$ and $7 \%$ ) (Table 2$)$.

$\mathrm{BrdU}$ label. Compared with the $1 \mathrm{~d}$ post-gentamicin group, a dramatic increase in the number of BrdU-labeled cells was noted with an average of 218 labeled nuclei in the proximal, morphologically damaged end of the epithelium (Fig. $5 c, d$, insets; Table 3 ). In marked contrast, an average of only 1 labeled cell was found in the distal, morphologically undamaged end which did not differ from controls.

After the third day following gentamicin injection, it was common to see pairs of BrdU-labeled nuclei in the proximal, 

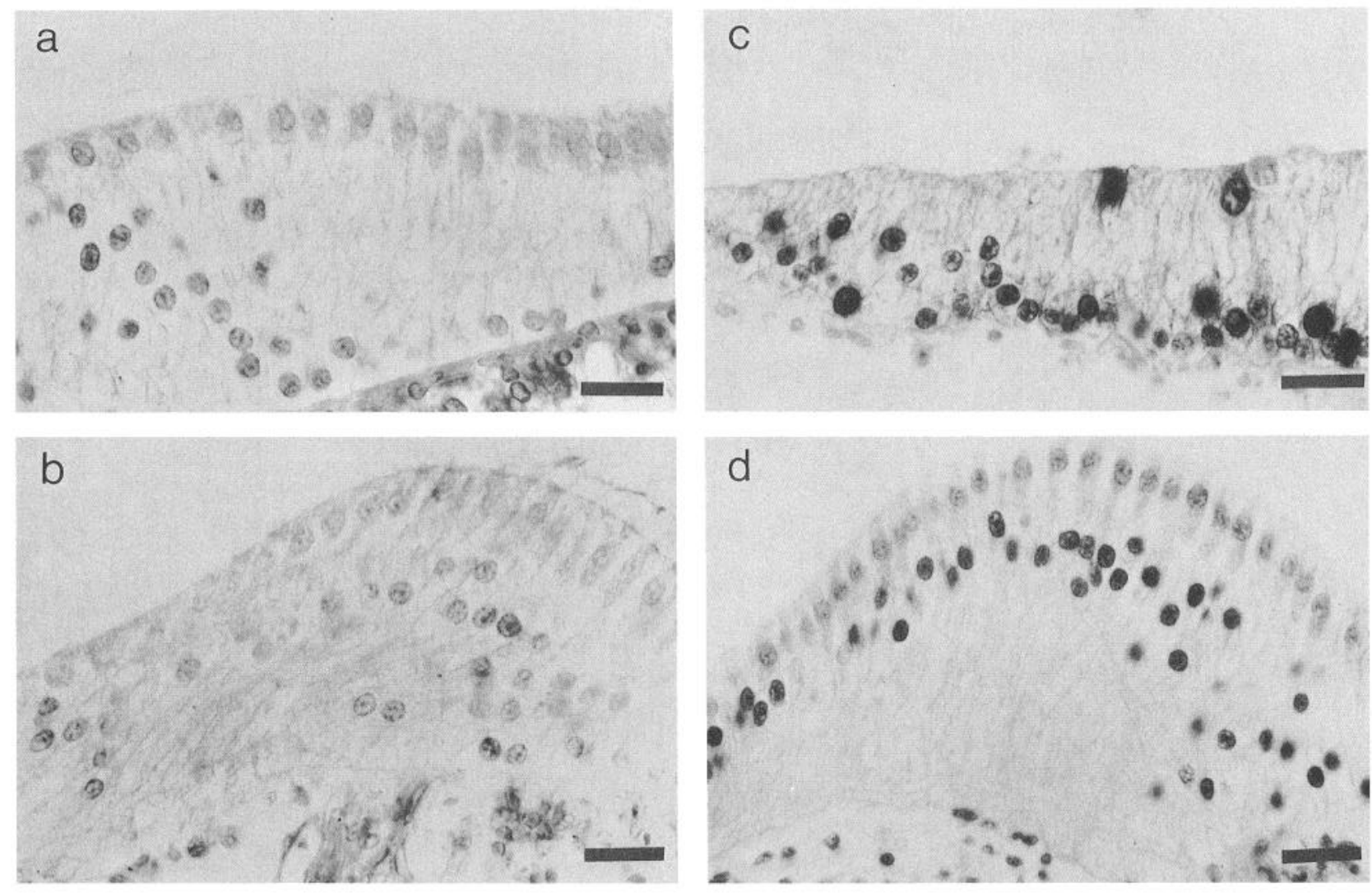

Figure 4. Photomicrographs of PCNA immunohistochemical staining. $a$ and $b$, Normal control cochlea demonstrating a low percentage of PCNA positive cells in the proximal $(a)$ and distal $(b)$ regions, $c, d$, Five days post-gentamicin: PCNA expression increases in both the proximal $(c)$ and distal $(d)$ regions. Scale bars: $a, 20 \mu \mathrm{m} ; b-d, 30 \mu \mathrm{m}$.

morphologically damaged region of the sensory epithelium. The close apposition of the paired nuclei suggests that the pairs represent daughter cells following a single mitotic event. No paired cells were seen in the distal region.

\section{Five days post-gentamicin}

Scanning electron microscopy. By $5 \mathrm{~d}$ post-gentamicin injection, the morphologically damaged proximal region contained numerous newly regenerated hair cells with immature stereocilia bundles (Fig. 1d). The epithelium beyond the marginal zone still did not show any morphological signs of damage to the hair cell surfaces or stereocilia bundles.

Light microscopy. Total loss of hair cells in the $600 \mu \mathrm{m}$ region was seen. The $1200 \mu \mathrm{m}$ region again demonstrated significant hair cell loss but some hair cells were present in the superior segment. While it was difficult to identify new hair cells in the paraffin cross sections, the thickness of the epithelium appeared to be restored along with a shift in nuclei towards the lumenal surface. Interval sections at 1800 and $2400 \mu \mathrm{m}$ appeared morphologically normal.

Statin label. Mature hair cells at the proximal $600 \mu \mathrm{m}$ interval had been lost. Remaining hair cells at $1200 \mu \mathrm{m}$ demonstrated a small increase in statin labeling compared with $3 \mathrm{~d}(34 \%)$, but labeling was still significantly less than controls (Fig. $3 c$, $d$; Table 1). Hair cells at $1800 \mu \mathrm{m}$ and $2400 \mu \mathrm{m}$ demonstrated the same pattern of increase in statin labeling relative to the $3 \mathrm{~d}$ group (38\% and $28 \%$ respectively). Support cells at the proximal 600 $\mu \mathrm{m}$ interval demonstrated a further reduction in statin label compared with the $3 \mathrm{~d}$ animals $(6 \%)$. In contrast, support cells at the
$1200 \mu \mathrm{m}$ interval showed a slight increase in statin label compared with the 3 d post-gentamicin group (34\%) while the more distally located support cells $(1800$ and $2400 \mu \mathrm{m})$ remained unchanged in the proportion showing positive staining for statin (41\% and $30 \%$, respectively).

PCNA label. At 5 d post-gentamicin, again, no hair cells were labeled with PCNA. Compared with PCNA expression at $3 \mathrm{~d}$ post-gentamicin, there was no further increase in support cell labeling at the $600 \mu \mathrm{m}$ interval (33\%) (Fig. 4c, $d$; Table 2). However, a further increase in labeling was observed at the $1200 \mu \mathrm{m}$ interval $(65 \%)$ corresponding to the marginal zone of damage and in the morphologically undamaged distal end at $1800 \mu \mathrm{m}$ and $2400 \mu \mathrm{m}$ (40\% and $24 \%$, respectively).

BrdU label. By $5 \mathrm{~d}$ post-gentamicin, the number of BrdUlabeled cells had fallen to an average of 27 in the proximal, morphologically damaged region of the epithelium (Fig. $5 c, d$; Table 3). An average of only three unpaired, labeled nuclei were detected in the distal, morphologically undamaged region, which did not reliably differ from controls.

\section{Seven days post-gentamicin}

Light microscopy. By $7 \mathrm{~d}$ post-gentamicin numerous new hair cells were detected in the proximal $600 \mu \mathrm{m}$ and $1200 \mu \mathrm{m}$ intervals while the support cell cytoarchitecture appeared to be returning to normal. Hair cells and support cells at $1800 \mu \mathrm{m}$ and $2400 \mu \mathrm{m}$ appeared normal.

PCNA label. No PCNA labeled hair cells were detected. PCNA label in the support cells was reduced compared with the $5 \mathrm{~d}$ group across the entire length of the basilar papilla, but 

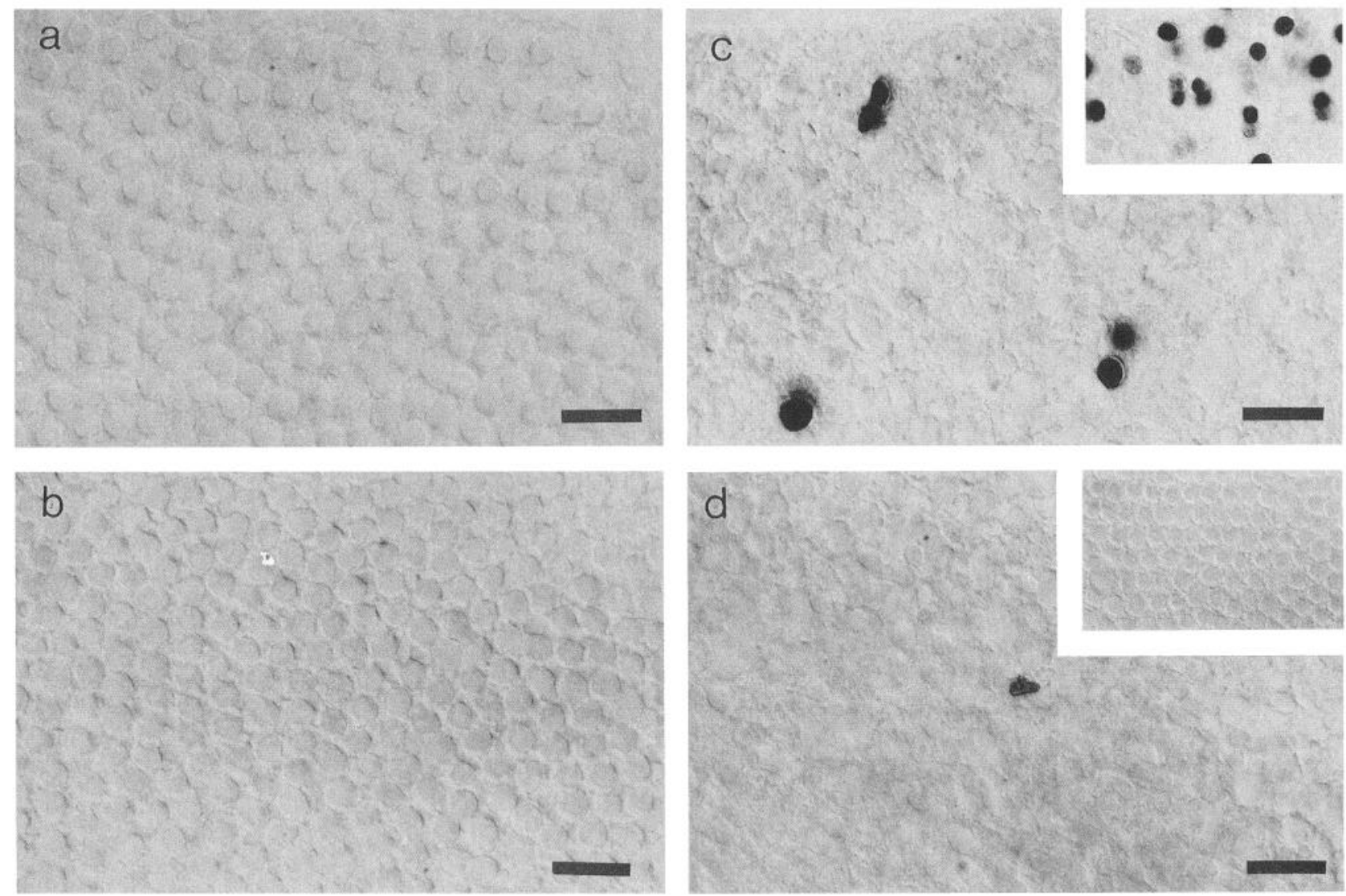

Figure 5. Photomicrographs of BrdU immunohistochemical staining in whole-mounts of chick cochlea. $a$ and $b$, Normal control cochlea demonstrating no BrdU positive cells in the proximal $(a)$ and distal $(b)$ regions. $c$ and $d$, Five days post-gentamicin BrdU staining is increased in the proximal region $(c)$ with the common occurrence of paired cells. In contrast the distal region $(d)$ is unchanged compared with controls with only extremely rare BrdU staining. Insets in $c$ and $d$ provide examples from a $3 \mathrm{~d}$ animal when the peak in BrdU incorporation occurred in the proximal region, while no change was noted in the distal region. Scale bars, $10 \mu \mathrm{m}$.

PCNA labeling was still elevated compared with the normal controls (Table 2).

BrdU label. At $7 \mathrm{~d}$ post-gentamicin, the number of BrdUlabeled cells approached the control levels with an average of three labeled nuclei in the proximal region and an average of two labeled nuclei in the distal region of the epithelium (Table 3 ). With the exception of one pair of cells, labeled nuclei in the distal morphologically undamaged region were not contiguous.

\section{Twenty days post-gentamicin}

Scanning electron microscopy. The basilar papilla in the proximal morphologically damaged region at $20 \mathrm{~d}$ post-gentamicin injection demonstrated significant numbers of regenerated hair cells with mature appearing stereocilia bundles and restoration of the hexagonal pattern. The orientation of hair cell stereocilia bundles was not as uniform as in the normal sensory epithelium. Additionally, hair cells appeared to be farther apart with increased surface areas while the lumenal surfaces of the support cells appeared to have returned to their normal size.

Light microscopy. In the proximal $600 \mu \mathrm{m}$ and $1200 \mu \mathrm{m}$ intervals numerous new hair cells were detected. The morphology was similar to undamaged hair cells in normal controls. Hair cells were loosely arranged particularly in the superior segment. Support cell layer morphology appeared normal. Interval sections at $1800 \mu \mathrm{m}$ and $2400 \mu \mathrm{m}$ remained unchanged.

Statin label. By $20 \mathrm{~d}$ post-gentamicin, statin expression in hair cells throughout the cochlea approached the levels seen in normal control cochleas $(65 \%$ and $92 \%$ at $600 \mu \mathrm{m}$ and $1200 \mu \mathrm{m}$, respectively; $73 \%$ and $66 \%$ at $1800 \mu \mathrm{m}$ and $2400 \mu \mathrm{m}$, respectively) (Table 1). Similarly, statin expression in the support cell population throughout the cochlea approached normal control levels.

PCNA label. Once again there were no PCNA positive hair cells. PCNA levels in the support cells remained elevated throughout the cochlea and were statistically equivalent to the 7 $\mathrm{d}$ animals (26\% and $29 \%$ at $600 \mu \mathrm{m}$ and $1200 \mu \mathrm{m} ; 40 \%$ and $14 \%$ at $1800 \mu \mathrm{m}$ and $2400 \mu \mathrm{m}$ ) (Table 2).

$\mathrm{BrdU}$ label. The lack of paired BrdU labeled cells in the distal, morphologically undamaged region suggested that the few cells that had entered $\mathrm{S}$ phase did not pass through mitosis during the $24 \mathrm{hr}$ following the initial BrdU injection. The alternative possibility, that one of the daughter cells had died and had been completely phagocytized, was considered unlikely during this short time period. To investigate the fate of the BrdU labeled cells in the distal, morphologically undamaged region, seven chicks were injected with BrdU at $5 \mathrm{~d}$ after gentamicin injection and were maintained for an additional $15 \mathrm{~d}$ prior to sacrifice (20 d post-gentamicin injection). Age-matched control animals ( $n=$ 3) consisted of chicks that did not receive gentamicin injection, but were given BrdU injections and sacrificed at the same time as chicks described above.

In $20 \mathrm{~d}$ control chicks an average of zero BrdU-labeled nuclei 
and an average of one labeled nucleus were found in the proximal and distal regions, respectively. In chicks that received a gentamicin injection an average of 22 labeled nuclei were detected in the proximal, morphologically damaged region while an average of 1 labeled nucleus was found in the distal, morphologically undamaged region (Table 3). At $20 \mathrm{~d}$, there were several sets of paired nuclei in the proximal, morphologically damaged region but only single labeled nuclei in the distal, nnorphologically undamaged region. In the distal region, none of the BrdU labeled nuclei appeared to belong to a hair cell. These results were qualitatively and quantitatively similar to the $5 \mathrm{~d}$ short term post-BrdU chicks for both regions. These findings suggest that the few cells in the undamaged region that incorporated BrdU on day 5 after gentamicin injection were arrested in a premitotic state and failed to divide in the $15 \mathrm{~d}$ period between BrdU injection and analysis.

\section{Discussion}

For hair cell regeneration to occur, a number of events must be regulated including stimulation of precursor cell proliferation, differentiation of daughter cells into hair cells, and inhibition of further proliferation among the precursor cells once hair cell repopulation has occurred. Recent studies have begun to investigate diffusible factors and candidate molecules that may trigger mitotic activity, but little is known regarding the events that precede mitotic activity (Lambert, 1994; Oesterle et al., 1994; Tsue et al., 1994a; Yamashita and Oesterle, 1994). The purpose of this study was to further elucidate the temporal and spatial patterns of events that may regulate progression of precursor cells through the cell cycle following application of an ototoxic agent in the chick.

The cell cycle is traditionally divided into four "active" phases $\left(G_{1}, S, G_{2}\right.$, and $\left.M\right)$ and a resting phase $\left(G_{0}\right)$. A number of checkpoints exist throughout the cell cycle to prevent cells from entering it or progressing beyond certain points; these checkpoints aid in regulating and synchronizing proliferation among cell populations (Hartwell, 1991; Nasmyth and Hunt, 1993). In this study, three cell cycle-associated markers, statin, PCNA, and BrdU, were used to locate cycling sensory epithelial cells temporally and spatially.

Statin is a $57 \mathrm{kDa}$ nuclear protein that is immunohistochemically detectable in quiescent cells in the $G_{0}$ phase and in terminally differentiated cells. Originally described by Wang (Wang, 1985a,b), statin has been characterized as a phosphoprotein whose function is incompletely understood (Lee et al., 1992). In vitro, induction of statin expression occurs during TGF- $\beta$ induced quiescence of lymphoblastic cell lines and in astroglial cell line terminal differentiation (Fedoroff et al., 1990; Ignotz, 1992). Conversely, as growth-arrested fibroblasts are induced to enter $G_{1}$, statin expression is lost (Wang and Lin, 1986; Ching and Wang, 1990; Pellicciari et al., 1991). In vivo, statin expression is decreased as quiescent liver cells are induced to proliferate in response to hepatectomy (Sandig et al., 1994).

Proliferating cell nuclear antigen (PCNA) is a subunit of DNA polymerase delta (Bravo et al., 1987). As such, its expression increases in late $G_{1}$ and $S$ phase of the cell cycle when it is needed for DNA replication. Interpretation of PCNA as a proliferation marker is complicated by the existence of two forms of PCNA which are differentially affected by fixation (Bravo and Macdonald-Bravo, 1987). In formalin-fixed tissue, a persistent form of PCNA can be detected which is not necessarily associated with proliferation. In alcohol-fixed and methanol-Car-

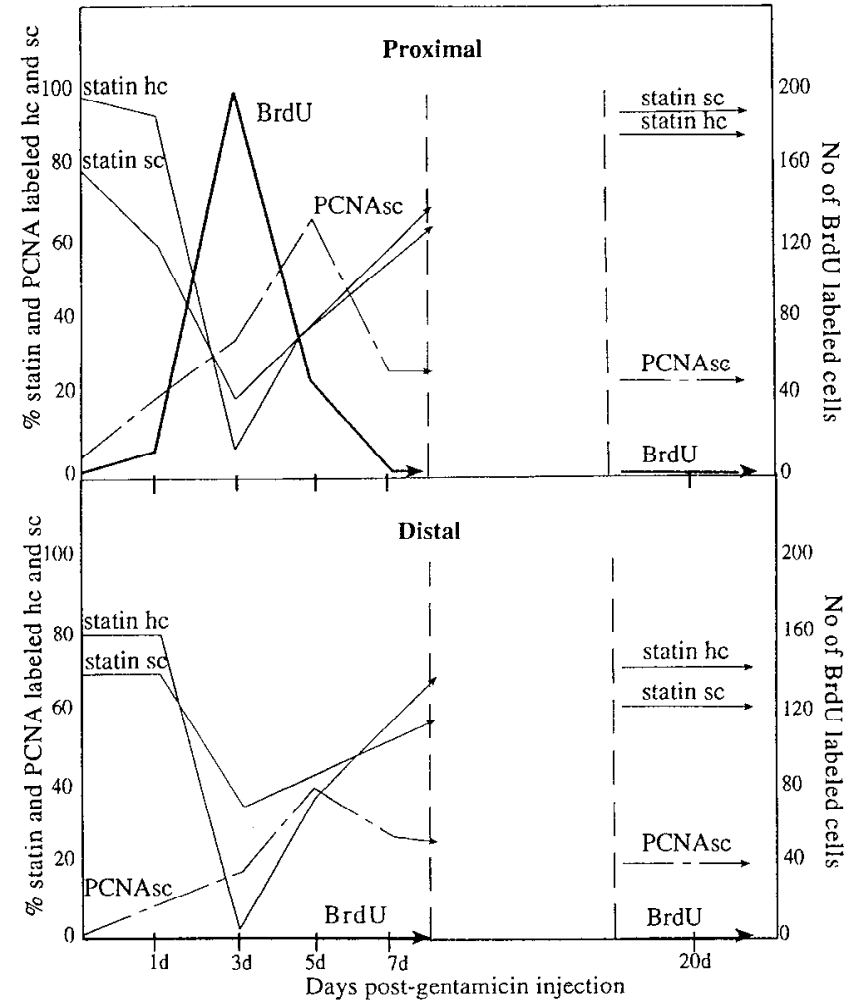

Figure 6. Comparison of the variations in immunostaining for statin, PCN $\Lambda$ and BrdU as a function of survival time after gentamicin injection. $s c$, Support cell; $h c$, hair cell.

noys-fixed tissues, as used in this study, only the proliferationassociated form is retained and PCNA detection is associated with late $G_{1}, S$, and early $G_{2}$ phases of the cell cycle (Bravo and Macdonald-Bravo, 1987; Galand and Degraef, 1989; Garcia et al., 1989). Peak levels of PCNA do vary in different cell types and levels found in late $S$ or early $\mathrm{G} 2$ phases of the cell cycle may be below the immunocytochemically detectable threshold (Takahashi and Caviness, 1993).

BrdU, a thymidine analog, is incorporatcd into the ncw DNA strands during S phase of the cell cycle (Gratzner, 1982). Once incorporated, BrdU is retained in DNA as it is passed to daughter cells following successive rounds of mitosis. In cochleas that are examined shortly after BrdU injection, BrdU labeling represents a "snapshot" of the cells that progressed through S phase during the time of BrdU injection. In cochleas that are examined Iong after BrdU injection, BrdU staining reveals the fate of cells which had gone through $\mathrm{S}$ phase around the time of BrdU injection.

In this study, chicks that did not receive gentamicin injection displayed high levels of statin expression and low levels of PCNA expression in all regions of the cochlear epithelium. In the case of the hair cells, PCNA labeling was nonexistent. These findings are consistent with previous studies that have detected little or no mitotic activity in the normal avian cochlea (Corwin and Cotanche, 1988; Ryals and Rubel, 1988; Oesterle and Rubel, 1993). Following gentamicin injection, both hair cells and support cells throughout the cochlear epithelium underwent changes in their cell cycle status (Fig. 6). A decrease in statin expression and a concomitant increase in PCNA expression were evident in support cells within the first $24 \mathrm{hr}$ after gentamicin injection, implying that a sizable number of support cells left their resting 


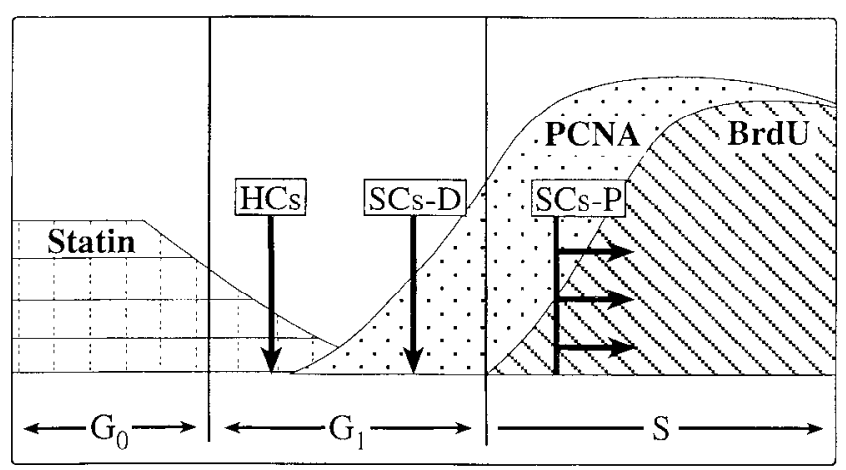

Figure 7. Summary of cell cycle events in hair cells and support cells based on the immunohistochemical detection of statin, PCNA, and BrdU. Progression of cells into the cell cycle varied with cell type and cochlear location. $H C s$, Hair cells; $S C s-D$, distal support cells; SCs-P, proximal support cells.

$\mathrm{G}_{0}$ state and progressed as far as late $\mathrm{G}_{1}$ (Fig. 7). Interestingly, these changes were detected prior to microscopic evidence of drug-induced morphological damage to the sensory epithelium. Also notable was the fact that changes in these two cell cycle markers were not confined to the proximal region, which was destined to demonstrate hair cell loss. Rather, support cells in the distal region, which did not sustain detectable injury following a single gentamicin injection, demonstrated delayed changes in statin and PCNA expression. However, evidence of support cell progression into $S$ phase (BrdU incorporation) was detected only after hair cell loss occurred ( $3 \mathrm{~d}$ after gentamicin injection) and was restricted to the morphologically damaged, proximal epithelium (Fig. 6). Furthermore, BrdU labeling decreased dramatically at $5 \mathrm{~d}$ after gentamicin injection. This decrease coincided with the appearance of new hair cells in the proximal epithelium. In the distal region where the hair cell population remained intact, there was no identifiable increase in BrdU incorporation at any of the time points examined.

In parallel with the support cell population, hair cells demonstrated a decrease in statin expression with proximal hair cells preceding distal hair cells. Notably, no demonstrable PCNA expression was found in hair cells at any time following gentamicin injection. This finding is consistent with previous studies that have examined short-term incorporation of $S$ phase markers in the cochlear epithelium (Oesterle and Rubel, 1993; Stone and Cotanche, 1994). These data provide further evidence that new hair cells do not arise from other hair cells but rather from the support cell population.

Comparison of the cell cycle associated markers in the proximal, morphologically damaged region with the distal, morphologically undamaged region provides evidence for a widespread direct or indirect response to gentamicin among cells of the cochlear epithelium. With the loss of statin expression and increase in PCNA expression, support cells throughout the cochlea appear to be stimulated to leave $G_{0}$ and progress to late $G_{1}$ (Figs. 6,7 ). Such a global response has not been previously described and may represent cellular changes that are mediated by gentamicin itself or by a diffusible factor. On the other hand, progression of support cells into $S$ phase is restricted to the proximal morphologically damaged region. Thus, the stimulus for DNA replication must be localized to the region of morphological cellular damage and/or loss. One possible stimulus is the extrusion and loss of hair cells thereby altering cellular contacts (Cotanche, 1987; Corwin et al., 1991). While progression through $S$ phase and mitosis effectively ceases by $7 \mathrm{~d}$ postgentamicin, PCNA and statin levels remain affected after $20 \mathrm{~d}$. This suggests persistence of some stimulus or growth factor even after hair cell repopulation.

In the present study we also observed a very small number of BrdU labeled cells in the distal half of the cochleas of both control and gentamicin treated animals. The fate of these BrdU labeled cells in the distal, morphologically undamaged region was explored. In the proximal, morphologically damaged region, the BrdU data clearly show consistent production of paired cells. The evidence suggests that at least some of these paired cclls are daughter cells which further implies that support cells are able to progress from $S$ phase through mitosis within the $24 \mathrm{hr}$ period from the first BrdU injection to sacrifice. Cell cycle times on this order have been previously described for chick cochlear support cells (Raphael, 1992; Stone and Cotanche, 1992). Pairs of BrdU-labeled cells were rarely seen in the distal morphologically undamaged region even $15 \mathrm{~d}$ after BrdU injection. Two possible interpretations of this finding are as follows: support cells in the distal end enter $\mathrm{S}$ phase, but fail to progress through mitosis (i.e., are arrested in $\mathrm{G}_{2}$ phase) or support cells in the distal end successfully divide, but one of the daughter cells dies and is phagocytized. In the absence of evidence for efficient macrophage infiltration of the morphologically intact epithelium, it seems unlikely that the cells are phagocytized within the 24 hr following BrdU uptake. On the other hand, while $\mathrm{G}_{2}$ arrest is an acknowledged phenomenon and, indeed, is felt to be a central mechanism for completion of DNA repair prior to mitosis, it is not typically associated with long term cell survival (Hartwell, 1991; O’Connor et al., 1993).

\section{References}

Bhave S, Rubel EW, Coltrera MD (1994) Expression of PCNA and Statin in regenerating chick cochlea. Assoc Res Otolaryngol 17: $131 \mathrm{~A}$.

Bravo R, Macdonald-Bravo H (1987) Existence of two populations of cyclin/proliferating cell nuclear antigen during the cell cycle: association with DNA replication sites. J Cell Biol 105:1519-1551.

Bravo R, Frank R, Blundell PA, Macdonald BH (1987) Cyclin/PCNA is the auxiliary protein of DNA polymerase-delta. Nature 326:515517.

Ching G, Wang E (1990) Characterization of two populations of statin and the relationship of their syntheses to the state of cell proliferation. J Cell Biol 110:255-261.

Corwin JT (1985) Perpetual production of hair cells and maturational changes in hair cell ultrastructure accompany postembryonic growth in an amphibian ear. Proc Natl Acad Sci USA 82:3911-3915.

Corwin JT, Cotanche DA (1988) Regeneration of sensory hair cells after acoustic trauma. Science 240:1772-1774.

Corwin JT, Jones JE, Katayama A, Kelley MW, Warchol ME (1991) Hair cell regeneration: the identities of progenitor cells, potential triggers and instructive cues. Ciba Found Symp 160:103-120.

Cotanche DA (1987) Regeneration of hair cell stereociliary bundles in the chick cochlea following severe acoustic trauma. Hear Res 30: 181-195.

Cruz RM, Lambert PR, Rubel EW (1987) Light microscopic evidence of hair cell regeneration after gentamicin toxicity in chick cochlea. Arch Otolaryngol Head Neck Surg 113:1058-1062.

Fedoroff S, Ahmed I, Wang E (1990) The relationship of expression of statin, the nuclear protein of nonproliferating cells, to the differentiation and cell cycle of astroglia in cultures and in situ. J Neurosci Res 26:1-15.

Galand P, Degraef C (1989) Cyclin/PCNA immunostaining as an alternative to tritiated thymidine pulse labelling for marking $S$ phase cells in paraffin sections from animal and human tissues. Cell Tissue Kinet 22:383-392.

Garcia RL, Coltrera MD, Gown AM (1989) Analysis of proliferative grade using anti-PCNA/cyclin monoclonal antibodies in fixed, em- 
bedded tissues. Comparison with flow cytometric analysis. Ann J Pathol 134:733-739.

Girod DA, Duckert LG, Rubel EW (1989) Possible precursors of regenerated hair cells in the avian cochlea following acoustic trauma. Hear Res 42:175-194.

Gratzner HG (1982) Monoclonal antibody to 5-bromo- and 5-iododeoxyuridine: a new reagent for detection of DNA replication. Science 218:474-475.

Hartwell LH (1991) Twenty-five years of cell cycle genetics. Genetics 129:975-980.

Hsu SM, Soban E (1982) Color modification of diaminobenzidine (DAB) precipitation by metallic ions and its application for double immunohistochemistry. J Histochem Cytochem 30:1079-1082.

Ignotz RA (1992) Transforming growth factor-beta 1 induces expression of statin during differentiation of human promonocytic leukemia cells. J Cell Biochem 50:285-292.

Janas JD, Cotanche DA, Rubel EW (1994) Avian cochlear hair cell regeneration: a quantitative analysis of damage and recovery from single high dose gentamicin injection. Assoc Res Otolaryngol 17: $66 \mathrm{~A}$.

Jorgensen JM, Mathiesen C (1988) The avian inner ear. Continuous production of hair cells in vestibular sensory organs, but not in the auditory papilla. Naturwissenschaften 75:319-320.

Katayama A, Corwin JT (1993) Cochlear cytogenesis visualized through pulse labeling of chick embryos in culture. J Comp Neurol 333:28-40.

Lambert PR (1994) Inner ear hair cell regeneration in a mammal: identification of a triggering factor. Laryngoscope 104:701-718.

Lee MJ, Sandig M, Wang E (1992) Statin, a protein specifically present in nonproliferating cells, is a phosphoprotein and forms a complex with a 45-kilodalton serine/threonine kinase. J Biol Chem 267: 21773-21781.

Manley GA (1990) Peripheral hearing mechanisms in reptiles and birds. New York: Springer.

Nasmyth K, Hunt T (1993) Cell cycle. Dams and sluices. Nature 366: 634-635.

O'Connor PM, Ferris DK, Pagano M, Draetta G, Pines J, Hunter T, et al. (1993) G2 delay induced by nitrogen mustard in human cells affects cyclin $\mathrm{A} / \mathrm{cdk} 2$ and cyclin B1/cdc2-kinase complexes differently. J Biol Chem 268:8298-8308.

Oesterle EC, Rubel EW (1993) Postnatal production of supporting cells in the chick cochlea. Hear Res 66:213-224.

Oesterle EC, Tsue TT, Rubel EW (1994) Mitogenic effects of insulin and IGF- 1 on cultured vestibular sensory epithelium from the avian inner ear. Assoc Res Otolaryngol 17:114A.

Pellicciari C, Danova M, Giordano M, Fuhrman-Conti AM, Mazzini G, Wang E, et al. (1991) Expression of cell cycle related proteinsproliferating cell nuclear antigen (PCNA) and statin-during adaptation and de-adaptation of EUE cells to a hypertonic medium. Cell Prolif 24:469-479.
Popper AN, Hoxter B (1990) Growth of a fish ear. II. Locations of newly proliferated sensory hair cells in the saccular epithelium of Astronotus ocellatus. Hear Res 45:33-40.

Presson JC, Popper AN (1990) Possible precursors to new hair cells, support cells, and Schwann cells in the ear of a post-embryonic fish. Hear Res 46:9-21.

Raphael Y (1992) Evidence for supporting cell mitosis in response to acoustic trauma in the avian inner ear. J Neurocytol 21:663-671.

Roberson DF, Weisleder P. Bohrer PS, Rubel FW (1992) Ongoing production of sensory cells in the vestibular epithelium of the chick. Hear Res 57:166-174.

Ryals BM, Rubel EW (1988) Hair cell regeneration after acoustic trauma in adult Coturnix quail. Science 240:1774-1776.

Sandig M, Bissonnette R, Liu CH, Tomaszewski G, Wang E (1994) Characterization of $57 \mathrm{kDa}$ statin as a true Indarker for growth arrest in tissue by its disappearance from regenerating liver. J Cell Physiol 158:277-284

Stone JS, Cotanche DA (1992) Synchronization of hair cell regeneration in the chick cochlea following noise damage. J Cell Sci 102: $671-680$.

Stone JS, Cotanche DA (1994) Identification of the timing of S phase and patterns of cell proliferation during hair cell regeneration in the chick cochlea. J Comp Neurol 341:50-67.

Takahashi T, Caviness VS Jr. (1993) PCNA-binding to DNA at the G1/S transition in proliferating cells of the developing cerebral wall. J Neurocytol 22:1096 1102.

Takasaka T, Smith CA (1971) The structure and innervation of the pigeon's basilar papilla. J Ultrastruct Res 35:20-65.

Tsue TT, Oesterle EC, Rubel EW (1994a) Diffusible factors regulate hair cell regeneration in the avian inner ear. Proc Natl Acad Sci USA 91:1584-1588.

'I'sue I"I, Watling DL, Weisleder P, Coltrera MD, Rubel EW (1994b) Identification of hair cell progenitors and intermitotic migration of their nuclei in the normal and regenerating avian inner ear. $\mathbf{J}$ Neurosci $14: 140-152$

Wang E (1985a) A 57,000-mol-wt protein uniquely present in nonproliferating cells and senescent human fibroblasts. I Cell Biol 100.545551 .

Wang E (1985b) Rapid disappearance of statin, a nonproliferating and senescent cell specific protein, upon reentering the process of cell cycling. J Cell Biol 101:1695-1701.

Wang E, Lin SL (1986) Disappearance of statin, a protein marker for non-proliferating and senescent cells, following serunn-stinnulated cell cycle entry. Exp Cell Res 167:135-143.

Weisleder P, Rubel EW (1993) Hair cell regeneration after streptomycin toxicity in the avian vestibular epithelium. J Comp Neurol 331:97110.

Yamashita H, Oesterle EC (1994) Mitogenic effects of EGF and TGFalpha on cultured vestibular sensory epithelium from the mammalian inner ear. Assoc Res Otolaryngol 17:131 A. 